$\xi=-1$

\title{
The Historical Development of Hospitality in Makkah
}

\author{
Abdullah. S. Karban ${ }^{1,2}$, Mahmud. B.M. Jusan ${ }^{2 *}$, Abdul Halim. Hussein ${ }^{2}$, Naif. S. Al-Aboud ${ }^{1}$ \\ ${ }^{I}$ Faculty of Islamic Architecture, College of Engineering and Islamic Architecture, Umm Al-Qura University, Makkah, Saudi Arabia. \\ ${ }^{2}$ Department of Architecture, Faculty of Built Environment, Universiti Teknologi Malaysia, Johor Bahru, Malaysia \\ *Corresponding author E-mail: arch-ask@hotmail.com
}

\begin{abstract}
Islamic hospitality is a reflection of religious and cultural values and principles that aim to enhance unity, equity, and social relationships Despite its increase in demand by Muslims and even non-Muslims, the main principles of Islamic hospitality has been neglected due to the emergence of contemporary forms of hospitality. Therefore, the aim of this review paper is to establish a modern approach which will promote the concept of Islamic hospitality in Makkah. The Islamic hospitality in Makkah city was selected due to its recent transformation towards the contemporary concept of hospitality. To achieve the research aim, systematic literature review was conducted to evaluate the historical development of Islamic hospitality, and the challenges it has encountered recently. Afterwards, it was identified that Islamic hospitality in Makkah has witnessed significant changes such as: Ibrahimic Hospitality, Arabic Hospitality, Islamic Hospitality, and Contemporary Hospitality. Based on the aforementioned, this paper recommends modern strategy to redefining the concept of Islamic Hospitality. This will enable the Islamic hospitality in Makkah to retain its religious and cultural values and principles, rather than becoming a way of acquiring money and reflecting the commercial hospitality principles.
\end{abstract}

Keywords: Residents' roles, Hospitality, Islam, Makkah, Hajj, Islamic Hospitality

\section{Introduction}

Generally, hospitality is an important component for promoting religious, social, and economic aspects of human life. The real concept of hospitality or (Dhiyafah) can be described as doing good deeds to provide guests needs. According to Al-elaiwi, [1]; Shandy [2] , hospitality is one of the ethics or rituals that God commands believers to implement in their daily life. In Muslim believe, Prophet Ibrahim (PBUH) was the first man who provided hospitality to the guests [3]. Also, his wife (Hajar) (PBUH) was the first woman who provided hospitality in Makkah [4, 5]. Since then, hospitality became a great ethnic religious culture that Muslims and Arab have been practicing over centuries.

In $19^{\text {th }}$ century, hospitality in Makkah has been transformed towards its contemporary meaning, focusing more on the economic aspect rather than promoting the religious and social aspects. It becomes the main engine of tourism industry that encompassed even the religious cities due to the high demands of people to perform religious activities $[6,7,8]$. As such, the hospitality companies and investors monopolized the hospitality services especially in religious cities such as Makkah $[8,9,10]$. The transformation of hospitality to its contemporary meaning has negatively impacted the religious and social aspects of practicing it.

The dramatic change from the previous to the current hospitality concepts is attributed to change in human intensions and behavior. The intentions in Islam known as (Neeyah), is incredibly similar to motivation values [11]. According to Moghimi et al. [12]; Schwartz [13], peoples action, attitude, behavior, and relationships, are motivated by personal; or community values $[2,14,15]$. The previous concepts of hospitality in Makkah were oriented towards their Islamic and culture principles. Whereas, current concept of hospitality in Makkah is oriented toward its economic principles. Based on that, the hospitality in Makkah can be categorized into four stages as shows in figure 1.

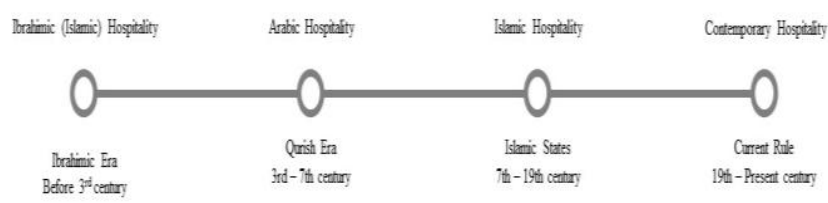

Fig: 1: Historical Development of Hospitality in Makkah

The figure above shows the development trend of hospitality in Makkah. As highlighted in the figure above, the hospitality in Makkah has deviated from its main purpose which is Islamic hospitality, to Contemporary hospitality.

Hence, it is paramount to create a new model for Islamic hospitality that delivers the real concept of Islamic hospitality, through enhancing the congruence between religious, social, economic, and environmental aspects in a modern form. As opined by Saleh; Belk \& Sobh [16]; SPA [17]; Stephenson [15] , there is a need to construct a hospitality model that provides stakeholders preferences and expatiations. The Therefore, the aim of this review paper is to establish a modern approach which will promote the concept of Islamic hospitality in Makkah. The city of Makkah was selected as proper example for this study due to its religious standing for billions of Muslims. To achieve the research aim, an overview of historical development of hospitality practice in the sacred city of Makkah was evaluated via systematic literature review. As stated by Alsolami \& Embi [18], systematic literature review offer an effective process of extracting and analyzing related literature. Thus, it is necessary, to understand deeply the historical patterns of Islamic hospitality, in order to fill the gap that exits in this regard [19, 20, 21, 22]. 
After systematic review of related literature, the study identified the need to develop a hospitality model which will address the needs of rapidly increasing number of pilgrims and visitor's. The hospitality model will be developed will promote the concept and the principles of Islamic hospitality in Makkah. However, this paper will significantly contribute to the development of knowledge by highlighting the significant changes and their causes as well as identifying the elements of hospitality components in Makkah to consider them in the future model. Also, it will contribute to correcting the misconception or limited understanding of Islamic hospitality that were carried by other studies.

\section{Literature Review}

\subsection{The Holy City of Makkah Al-Mukaramah}

Makkah is the sacred capital city for Muslims. Makkah was revised during the time of prophet Ibrahim (PBUH) in 4400 BEC, when he left his wife (Hajar) and their child (Ismail) (PBUT) in an uncultivated valley near the sacred House of God named the Ka'aba [23, 24, 25]. According to Islamic studies, Makkah valley was empty and there was no source of living, so Hagar was climbing the two mountains of Safa and Marwah looking for any source of water. Miraculously, the holy water of Zamzam appeared and became a source of life in Makkah [4, 26, 27]. This was believed to be Gods responds to prophet Ibrahim's (PBUH) prayer as stated in the holy Quran..

"Our Lord, I have settled some of my descendants in an uncultivated valley near Your sacred House, our Lord, that they may establish prayer. So make hearts among the people incline toward them and provide for them from the fruits that they might be grateful" (Ibrahim verse, 37).

Afterwards, people started going to Makkah, which eventually led to the establishment of the early community in Makkah. After that Allah (SWT) (Almighty) asked prophet Ibrahim (PBUH) to rebuild the Ka'aba and purify it for prayers, pilgrims, and believers [28, 29]. Then, Allah (SWT) (Almighty) commanded prophet Ibrahim (PBUH) to rebuild, clean and purify the Ka'aba and announce to all mankind to perform Hajj ritual. Since then, the number of guests of Allah (SWT) (pilgrims and visitors) have been rabidly increasing to gain the benefits of performing Islamic rituals in the most holistic place on earth $[30,31,32]$.

\subsection{Hajj and Umrah Seasons}

Muslims intend to perform Hajj and Umrah rituals in order to relief their sins and gain redoubled rewards from Allah called ( $\mathrm{Ajr}$ or Thawab) due the privilege of the place and the time [30, 33]. Therefore, Makkah city witness the highest number of guests during the three specific seasons namely: Hajj season, Ramadan, and Al-Mawlid Al-Nabawi. According to Islamic tradition, Hajj (pilgrimage) is the fifth pillar that which is practiced during wellknown days - Thul-Hijjah, the last month of Islamic calendar. Moreover, it is an obligatory pillar for all eligible and capable Muslims at least once in their life [15, 33]. While, Umrah considers as good deed that can be practiced any time. Muslims believe that, preforming Umrah during the month of Ramadhan- the $9^{\text {th }}$ month of Islamic calendar has equal rewards as preforming Hajj with prophet Mohammad (PBUH). However, many Muslims intend to preform Umrah when they come to celebrate Al-Mawlid Al-Nabawi -the birthday of prophet Mohammad (PBUH)- during the third month of Islamic calendar. Nevertheless, Muslims prefers to visit Makkah during the virtue event to gain the privilege of the time and the place which led to increasing the numbers of visitors and Makkah remains almost full through the year.

\subsection{Guests of Allah (SWT)}

Guests of Allah (SWT) or Dheuof Al-Rahman are pilgrims and visitors who come to Makkah to perform Islamic rituals. Since the construction of Ka'aba, the number of pilgrims and visitors has increased greatly. [36] reported that the numbers of pilgrims and visitors continues to increase especially during Hajj and Umrah during the month of Ramadhan seasons. According to General Authority of Statistics 2017 report, the highest numbers of pilgrims was recorded during the 2012 Hajj season, exceeding 3.16 million pilgrims with an average duration of stay of about three weeks. Subsequently, the number reduced to less than 1.86 million pilgrims in 2016, due to different major factors such as; importantly, global economic crisis, spread of epidemics and the constructions works of the holy mosques. Nevertheless, recent statistics indicates that the number of pilgrims have increased beyond 2.35 million pilgrims [34, 35, 36, 37]. While, in 2016, the Ministry of Hajj and Umrah and The General Authority of Statistics projected that the number of visitors and pilgrims will continue to increase in coming years.

However, due to the high intentions of Muslims to preforms these rituals, the Saudi government aims to increase the capacity and quality of the hospitality services to serve more than 15 million foreign visitors by 2020 and over 30 million pilgrims and visitors by 2030 [38]. Thus, subsequent section investigates the historical development of hospitality practice, especially in the Holy city of Makkah. This is to enable us to actualize the aim of this study.

\subsection{The Concepts of Hospitality}

The concept of Hospitality is fairly vague due to differences of encompassing relationships between guests and hosts which is derived from their social, economic and environment aspects. Indeed, there is no agreed definition of hospitality among scholars and nations [39]. Generally, oxford dictionary defined hospitality as "The friendly and generous reception and entertainment of guests, visitors, or strangers"[40]. Despite the numerous existing literature on hospitality, there is still a gap in conceptualizing hospitality among the various aspects of culture and religion. Hospitality is classified into two; social aspect and economic (industry) aspect. The former includes the religion and culture perspectives while the later focuses the tourism and commercial perspectives of hospitality $[1,2,15,20,41,42]$.

In this regard, this paper concentrates more on the social aspects of hospitality in Makkah, though it highlights some economic and environmental issues. This is necessary, considering the fact that there are only a few literatures documented with respect to the environmental aspect of hospitality. Most of recent research discussed hospitality in limited context through some religious, cultural events and activities and through the economic aspect of tourism industry [15, 43]Despite of origin of the hospitality concept rooted back to early ages, it is still a young field within research discipline.

\section{Development of Hospitality Practice in Makkah}

\subsection{Ibrahimic (Islamic) Hospitality}

Hospitality is one of prophet Ibrahim (PBUH) ethics that reflects the Islamic teachings ("KSU - Electronic Moshaf project," 2018). Eliciting from the historical studies, Hajar (PBUH)- prophet Ibrahim's (PBUH) wife, was the first women to provide hospitality in Makkah about 3700 years ago [5, 24, 26]. She learned the hospitality ethics from prophet Ibrahim (PBUH) when he hosted his guests, providing them with water, food, and shelter. Therefore, Hajar (PBUH) hosted an entire Yemenis tribe called Jorhom. At that time, Jorhom tribe always traveled from Yemen to Al-Sham looking for water sources and an appropriate place to live. On 
their way to Al-Sham, they witnessed birds flying around Zamzam well in Makkah as sign of availability of water and life. They came to Makkah and Hajar (PBUH) welcomed and hospitalized them by sharing the Zamzam water and allowed them to settle in Makkah [4, 26, 44, 45, 46]. Afterwards, Allah (SWT) (Almighty) commanded prophet Ibrahim and his son (PBUT) the residents of Makkah at that time, to rebuild the Ka'aba, to prepare, purify, and secure it for prayers and pilgrims, and to announce Hajj to all human being. According to Islamic literature, the people have been coming to Makkah because God's responded to prophet Ibrahim's (PBUH) prayers as motioned in the Holy Quran as stated in the words of prophet Ibrahim (PBUH):

"Our Lord, I have settled some of my descendants in an uncultivated valley near Your sacred House, our Lord, that they may establish prayer. So make hearts among the people incline toward them and provide for them from the fruits that they might be grateful" Surah Ibrahim, verse 37. [27].

Since then, the hospitality has become a privilege and an obligation to Makkah's residence, in compliance with Allah (SWT)'s commands to follow prophet Ibrahim (PBUH) Islamic ethics of hospitality. According to Al-sulamy [47]; Maddah [32]; Saboon [3], prophet Ibrahim (PBUH) was the first Mutawif to provide Dhiyafah (hospitality) to pilgrims. Dhiyafah was defined in Arabic language as hosting guests by providing water, food and shelter [2, $16,44]$.Through previous discussions, it is clear that prophet Ibrahim and his family (PBUT) followed by Makkah residents played a significant role in hosting the travelers by welcoming and providing their needs such as food and drinks, shelter, and security. This enhanced the brotherhoods and social relationships, and in turn achieves the Islamic purposes of building the earth.

\subsection{Arabic Hospitality}

Historians refer Arabic Hospitality as the recoded history of resident's roles in hosting guests during the $3^{\text {rd }}$ century. Hospitality at that time was limited. Where the elites were the only ones eligible to provide it to the guests. During that time Qusai bin Kelab -the ruler of Qurish tribe in Makkah- signed specific role to the elites of each clan to serve pilgrims by providing Dhiyafah. For instance, teaching and supervisory (Al-Tewaffah) was signed to the elites of each clan, thirst-quenching and feeding (Al-Seqayah \& Al-Refadah) was signed to Bano Hashim clan, alongside leadership (Al-Qeyadah), protection (Al-Hemayah) and many others [3, $4,5,6,25,47,48,49]$.

Although there are differences between their principles and values, The Arabic hospitality by its meaning is similar to Ibrahimic (Islamic). Yet, the Qurish tribe practised Arabic hospitality in order to gain pride among other tribes $[2,16,25,29]$. Also, they consider it as good deeds that idols and God would accept. Moreover, Qurish tribe had been proud of providing hospitality to the pilgrims even after Islam arise. According to Holy Quran in sura Al-Tawba verse 19.

"Have you made the provision of water for the pilgrim and the maintenance of al-Masjid al-Haram equal to [the deeds of] one who believes in Allah (SWT) and the Last Day and strives in the cause of Allah (SWT)? They are not equal in the sight of Allah (SWT). And Allah (SWT) does not guide the wrongdoing people." Surah Al-Tawba verse 19 [27].

In the previous verse, Allah (SWT) (Almighty) denied the arrogance and pride of Qurish tribe in providing hospitality to pilgrims and made it equal deed to believe in Islam. This reflects that, hospitality and doing good deeds should be driven from their Islamic principles and intentions. Hospitality in its original concept aims to enhance unity and social relationship, thus it requires ampleness and sacrifice. This contradicts the Arabic hospitality practiced by Qurish tribe because they did not apply the original concepts of hospitality that was in Ibrahimic teachings. Alternatively, providing Arabic hospitality in order to gain pride and show off among other people will weaken the social relationships and cause a lot of discord which differ from teachings of Islam. Thus, Allah (SWT)
(Almighty) sent his prophet Mohammad (PBUH) to revive the Islam and to enhance the good ethics and morals which hospitality is one of them.

\subsection{Islamic Hospitality}

Hospitality in Makkah witnessed significant changes since the Islam emerged during $7^{\text {th }}$ century. Islam changed the roles of Arabic hospitality that implement obscurity principles and concepts that were practiced by Qurish tribe. On the other hand, Islam improved the intentions and the motivations of people to provide hospitality to implement honor, equity and high morals, which enhance the Islamic principles and values. For instance, Islamic teaching improved the principles of Arabic Dhiyafah by giving all residents equal rights to participate in serving and hosting pilgrims $[5,25]$. Thus, the role of Arabic Dhiyafah was converted to the role of Islamic Dhiyafah. According to Islamic traditions, Islamic Dhiyafah is defined as an obligatory rite for and to all Muslims by providing food, water and shelter for three days and nights for the sake of Allah (SWT). Anything beyond hosting guests more than one day and night is considered charity (Sadaqah) [2, 15, 16, 42]. Hence, most residents of Makkah were hosted guests of Allah (SWT) to gain redoubled reward from Allah (SWT) due to the great privilege of Makkah.

Moreover, during the early Islamic period and Islamic states, the residents contributed in providing Islamic Dhiyafah. At that time, the new concepts of Waqf and Rebat has emerged to support the concept of Islamic hospitality. According to N. Hassan, Abdulrahman, \& Yazid [50]; Mohammad \& Mar Iman [51] , Waqf defined is a religious endowment. Therefore, some of Makkah residents and other Muslims were Waqf (holding) their houses partly or completely to accommodate pilgrims and visitors in Makkah [5, $45,52]$. Also, a lot of them were Waqf (holding) a signed amount or percentage of their income to provide hospitality to the guests of Allah (SWT). Also, Rebat which is another concept associated with the hospitality in Makkah, started in early Islamic age. Rebat in its origin was guardhouse located within the boundaries of the city to provide protection during wars. After wars ended, due to the strategic location of Rebat, Rebat became a place for ascetic worshipers who hosted travellers of Allah (SWT). Over time Rebat became a place of shelter and subsistence and social care for travellers, poor people, orphans, widows, divorced women, and seniors [5, 45, 52]. Both Waqf and Rebat have great principles that support the concept of Islamic hospitality. According to Stephenson [15] , Islamic teachings helps to shape and condition peoples' behaviors.

Although Waqf and Rebat still exist in Makkah, critics have argued that the orientation has shifted towards commercial aspects, whereby the benefits are transferred or hijacked by the stakeholders. In the last few decades, previous study have revealed that Islamic hospitality in Makkah has exceeded its religious and social boundaries headed toward the economic aspect of hospitality which can be called the contemporary hospitality.

\subsection{Contemporary Hospitality}

Over the past few decades, some of the Makkah's resident have used used the Islamic Dhiyafah as a source of income, due to the increasing numbers of pilgrims and visitors to Makkah. Overtime, specifically during early $19^{\text {th }}$ century, due to several factors such as weakness in political control and security, deterioration of socio-economic conditions, some Makkah residents somehow don't treat the guests of Allah (SWT) as expected [4, 5, 48, 53, 54]. They manipulated their houses and places in Makkah as well as food and drinks and asked for high prices [55]. Although Tewaffah services were initiated to address the new concept of contemporary hospitality, the practces by the Makkah residents did not the Islamic teaching. Tewaffah is a profession for religious scholars named Mutawif who teach and guide non-Arabic speakers on how to perform Hajj $[26,31,48,49,56]$. However the social 
segregation lead to outflow of worshippers in Waqf and Rebat in Makkah, due to inabulity to pay inflated prices for shelter, food, etc.

During the $20^{\text {th }}$ century, the commercial concept of hospitality was developed to be a hospitality industry. Because of the increased number of pilgrims and visitors and the exploitation of them by hosts, the hospitality industry sectors found Makkah as proper market for them. Therefore, current principles of hospitality services were commercialized. Several studies stated indicated that hospitality is considered as the engine of tourism industry where, the contemporary meaning of hospitality refers to services, hotels, restaurants and events sectors [15, 57]. Hence, several researchers postulated that, Hajj and Umrah rituals are religious tourism and economic source, which can be managed by hospitality and tourism industries. Moreover, Al Amoudy, [6]; Alotaibi, [7]; Jafari \& Scott, [58] concluded that, Makkah's hospitality market is one of the fastest and high demand market in Middle East. Thus, foreign companies and private sectors are strongly competing to invest in hospitality market in Makkah, providing low quality services to make high profits.

Thus, Saudi government attempted to regulate and institutionalise a cooperative system between countries' agencies, Tewaffah establishments, and tourism and hospitality sectors, to insure better services [17, 31, 48]. Saudi government considers provision of hospitality services as a fundamental religious obligation which supports the principles of traditional Islamic hospitality established by Allah (SWT). Therefore, Saudi government, been supporting this sectors to provide better services with affordable cost. Unfortunately, the system gives opportunity to tourism and hospitality sectors to dominated hospitality services which differ from the aim of Saudi government. As stated by prince Khaled AlFaisal -the ruler of Makkah region-, during the final press conference for Hajj in 2017, Hajj is a religious rite for all Muslim to worship Allah (SWT) and Makkah is not a market for hospitality industry by its commercial meaning $[59,60,61,62]$. Therefore, it is important to correct concepts of providing hospitality services among stakeholders. Whereas, the concept and principles of contemporary hospitality doesn't achieve the religious and social purposes of providing hospitality.

\section{Conclusion}

Through systematic literature review, this paper studied the historical development of hospitality in most important city for Muslims. Hence, the concepts, principles, and goals of Islamic hospitality were highlighted. Nevertheless, it was discovered that the Islamic hospitality in Makkah has deviated from its original purpose of providing shelter, food, etc., to worshippers. In fact, the hospitality in Makkah has been practiced through several concepts and principles including Ibrahimic (Islamic) Hospitality, Arabic Hospitality, Islamic Hospitality and Contemporary Hospitality. The changes in hospitality concepts overtime were due to social and economic factors that influenced residents of Makkah to hosts guests.

Therefore, the contemporary Hospitality or other forms that are completely focused on financial benefits are not in line with Islamic hospitality. Because, the Islamic hospitality was found to enhance the structure of Muslim community by hosting travelers, poor or other people who need it. Therefore, this review paper established a modern approach which will promote the concept of Islamic hospitality in Makkah. The modern form of Islamic hospitality proposed in this study considers the Islamic teachings by enhancing the structure of Muslim community towards hosting of travellers, poor or other people in need. Also, there is no room for monopoly by specific group..

\section{References}

[1] Al-elaiwi AA (2014), Hospitality in Islam: An Islamic Juristic Economical Study (Arabic). International Islamic Marketing Association 3(3), 136-144. https://doi.org/10.12816/0007385

[2] Shandy I (2007), The rulings of hospitality in the Islamic Sharia (Arabic).

[3] Saboon AMH (2016), Services provided to the pilgrims of house of Allah before Islam and its relationship to the concept of AlTewaffah(Arabic). In Al-Tewaffah and Al-Mutawiffon. Makkah: King Salman Bin Abdulaziz Chair for Historic Makkah Studies.

[4] Al Sebai A (1999), Makkah History, Studies in politics, science, sociology, architecture (Arabic).pdf. Riyadh: Darah (King Abdulaziz Foundation for Research and Archives).

[5] AlSyriani MM (1986), Makkah Al Mokaramah Study in the development of urban growth (Arabic).pdf. Kuwait: Kuwait Geographical Society.

[6] Al Amoudy S (2014), Makkah Al-Mukaaramah: a second tier city for religious tourism. In City imaging: Regeneration, renewal and decay, 201-208. Springer.

[7] Alotaibi H (2016), Strategic Practices and Development of the Hotel Sector for Pilgrims in Makkah and Madinah. The International Journal of Business \& Management 4(1), 309-321.

[8] Jones Lang LaSalle (2010), Holy Cities: Saudi's Unique Real Estate Markets (Vol. 1440).

[9] Abdulraoof A (2014), From Makkah to Las Vegas: Critical treatises in architecture and holiness (Arabic) Ali Abdulraoof (2nd ed.). Cairo, Egypt: Madarat Publishing.

[10] Sardar Z (2014), Mecca. The Sacred City. LONDON: Bloomsbury Publishing Plc.

[11] Bukhari (2009), Sahih al-Bukhari. (M. M. Khan \& M. Al-Almany, Eds.).

[12] oghimi V, Jusan MBM, Izadpanahi P \& Mahdinejad J (2017), Incorporating user values into housing design through indirect user participation using MEC-QFD model. Journal of Building Engineering 9(November 2016), 76-83. https://doi.org/10.1016/j.jobe.2016.11.012

[13] Schwartz SH (1992), Universals in the content and structure of values: Theoretical advances and empirical tests in 20 countries. Advances in Experimental Social Psychology. https://doi.org/10.1016/S0065-2601(08)60281-6

[14] El-Aswad E-S (2015), Hospitality ( in Islam ). In Encyclopedia of Islam and the Muslim World (2nd ed., p. 462-).

[15] Stephenson ML (2014), Deciphering "Islamic hospitality": Developments, challenges and opportunities. Tourism Management, 40, 155-164. https://doi.org/10.1016/j.tourman.2013.05.002

[16] Belk R \& Sobh R (2013), Islamic Arab hospitality and multiculturalism. Marketing Theory, 13(4)(December), 443-463. https://doi.org/10.1177/1470593113499695

[17] SPA (2016), Minister of Hajj and Umrah inaugurates a workshop for the development of Tewaffah Establishment (Arabic). Saudi Press Agency.

[18] Alsolami BM \& Embi MR (2018), Crowding perception : A case study of developed systematic literature review procedure with multiple software programs as management and synthesis tools, (April). https://doi.org/10.14419/ijet.v7i2.10.10969

[19] Dwivedi YK, Venkitachalam K, Sharif AM, Al-Karaghouli W \& Weerakkody V (2011), Research trends in knowledge management: Analyzing the past and predicting the future. Information Systems

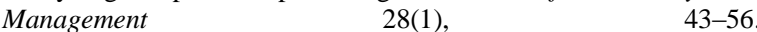
https://doi.org/10.1080/10580530.2011.536112

[20] Kim CS, Bai BH, Kim PB \& Chon K (2018), Review of reviews: A systematic analysis of review papers in the hospitality and tourism literature. International Journal of Hospitality Management 70(October 2017), 49-58. https://doi.org/10.1016/j.ijhm.2017.10.023

[21] Stylidis D, Biran A, Sit J \& Szivas EM (2014), Residents' support for tourism development: The role of residents' place image and perceived tourism impacts. Tourism Management, 45, 260-274. https://doi.org/10.1016/j.tourman.2014.05.006

[22] UNGA (2015), Transforming our world: The 2030 agenda for sustainable development. United Nations General Assembly. https://doi.org/10.1007/s13398-014-0173-7.2

[23] Al-Fakahi M (1994), Makkah News in an old age and modern (Arabic).pdf. (A. malek Bin Doheish, Ed.) (2nd ed.). beirut, lebanon.

[24] Ascoura IE (2013), Impact of Pilgrimage (Haji) on the Urban 
Growth of the Mecca. Journal of Educational and Social Research 3(May), 255-264. https://doi.org/10.5901/jesr.2013.v3n2p255

[25] Mohamad MAI (2009), Political organizations in Arab land before Islam(Arabic). University of Khartoum.

[26] Al-Azraqi M (2003), Makkah news (Arabic).pdf. (A. malek Bin Dohish, Ed.) (first). Makkah: Al Osdi.

[27] KSU - Electronic Moshaf project (2018).

[28] Al Sharif AI (1985), Makkah and Madina before ignorance and the prophet time (Arabic).pdf. Cairo: Dar Al Fekr Al Arabi.

[29] Ali J (1993), The Detailed in Arab History Before Islam (Arabic).pdf (2nd ed.). Baghdad: university of Baghdad.

[30] Al-Ken AI (1995), The Hajj : Past, Present, and Future.

[31] Bin Doheish AA (2016), Al-Tewaffah and Al-Mutawiffon and its historical development until the beginning of Saudi Rule. In AlTewaffah and Al-Mutawiffon. Makkah: King Salman Bin Abdulaziz Chair for Historic Makkah Studies.

[32] Maddah AAW (2016), Effects of Al-Tewaffah on Makkah society culturally, socially and economically since the 14th century until the present time(Arabic). In Al-Tewaffah and Al-Mutawiffon.

[33] Raj R \& Bozonelos D (2015), Pilgrimage Experience and Consumption of Travel to the City of Makkah for Hajj Ritual. International Journal of Religious Tourism and Pilgrimage 3(1), $38-45$.

[34] Almuhrzi HM \& Alsawafi AM (2017), Muslim perspectives on spiritual and religious travel beyond Hajj: Toward understanding motivations for Umrah travel in Oman. Tourism Management Perspectives, 24, 235-242. https://doi.org/10.1016/j.tmp.2017.07.016

[35] Alsolami BM, Embi MR \& Enegbumac WI (2017), The Influence of Sustainable Physical Factors on Hajj Crowd Perception among Internal Pilgrim Group in Mina. CHEMICAL ENGINEERING, 56, 409-.

[36] GASTAT (2017), Hajj Statistics 2017 - Arabic.

[37] GASTAT (2016), Umrah Survey 2016.

[38] Saudi Vision 2030. (2016). Saudi Vision 2030 (Arabic). Riyadh. https://doi.org/10.1017/CBO9781107415324.004

[39] Kirillova K, Gilmetdinova A \& Lehto X (2014), Interpretation of hospitality across religions. International Journal of Hospitality Management, 43, 23-34. https://doi.org/10.1016/j.ijhm.2014.07.008

[40] Oxford Dictionary (2018), Oxford Dictionaries.

[41] Levy SE (2010), The hospitality of the host: A cross-cultural examination of managerially facilitated consumer-to-consumer interactions. International Journal of Hospitality Management 29(2), 319-327. https://doi.org/10.1016/j.ijhm.2009.10.003

[42] Othman Z, Aird R \& Buys L (2015), Privacy, modesty, hospitality , and the design of Muslim homes : A literature review. Frontiers of Architectural Research, 4(1), 12-23. https://doi.org/10.1016/j.foar.2014.12.001

[43] Zamani-Farahani H \& Eid R (2016), Muslim world: A study of tourism \& pilgrimage among OIC Member States. Tourism Management Perspectives. Elsevier Ltd. https://doi.org/10.1016/j.tmp.2015.12.009

[44] Ali J (1993), the detailed in Arab history before Islam.pdf (2nd ed.). Baghdad: university of Baghdad.

[45] Hamo M (2014), Makkah Al Mokarmah Tarekh wa ma'alem (first). Jeddah: Al Madinah press.

[46] Hassan R (2006), Islamic Hagar and her family. Hagar, Sarah, and Their Children: Jewish, Christian, and Muslim Perspectives, 149167.

[47] Al-sulamy IA (2016), Al-Tewaffah Pronunciation and meaning historical-reading(Arabic). In Al-Tewaffah and Al-Mutawiffon 4378. Makkah: King Salman Bin Abdulaziz Chair for Historic Makkah Studies.

[48] Al-Mowani NA (2016), Al-Tewaffah professions, its function and its tasks evolution through the ages. In Al-Tewaffah and AlMutawiffon. Makkah: King Salman Bin Abdulaziz Chair for Historic Makkah Studies.

[49] Hariri MM (1986), Housing in Central Makkah: the influence of Hajj.

[50] Hassan N, Abdul-rahman A \& Yazid Z (2018), Developing a New Framework of Waqf Management. International Journal of Academic Research in Business \& Social Sciences 8(2), 287-305. https://doi.org/10.6007/IJARBSS/v8-i2/3872

[51] Mohammad MTS \& Mar Iman AH (2006), Obstacles of the Current Concept of Waqf to the Development of Waqf Properties and the Recommended Alternative. Malaysian Journal of Real Estate 1(1), 27-38. https://doi.org/10.1108/H-02-2015-0010

[52] Al-Hossaiean MA (1997), The role of Waqf in establishing schools and sheltters and maintenining them in Medina (Arabic).pdf. Journal of Architecture and Planning (JAP) 53-112.

[53] Hurgronje CS (1999), Safahat Men Tarekh Makkah. (A. Alsheuokh $\&$ M. N. Mirza, Eds.) (second).

[54] Miller M (2003), The Business of the Hajj Seaborne Commerce and the Movement of Peoples. In Seascapes, Littoral Cultures, and Trans-Oceanic Exchanges." Washington, DC: Library of Congress 12.

[55] Al-Batnoni ML (1909), the Hejaziah journey (Arabic). Ciro: AlThagafah Al-Deniyah.

[56] Edrees MA (2001), Urban Changes in the Residential Layouts in Makkah City, Saudi Arabia.

[57] Ariza-Montes A, Arjona-Fuentes JM, Han H \& Law R (2017), Employee responsibility and basic human values in the hospitality sector. International Journal of Hospitality Management 62, 78-87. https://doi.org/10.1016/j.ijhm.2016.12.001

[58] Jafari J \& Scott N (2014), Muslim world and its tourisms. Annals of Tourism Research. Elsevier Ltd. https://doi.org/10.1016/j.annals.2013.08.011

[59] SPA (2017 September) Prince Khalid Al-Faisal Announces the Success of This Year' s Hajj Season 3. Saudi Press Agency, p. 1663127.

[60] Sanil, H. S., Ramakrishnan, S., Alwethainani, M., Kazi, A. G., \& Siddique, M. (2016). Effectiveness of Supply Chain Management with Reference to Apparel Industry: A Case Study in India. International Review of Management and Marketing, 6(4S).

[61] Keong, L. B., Ramakrishnan, S., \& Hishan, S. S. (2017). The Review of Corporate Social Responsibility (CSR) Literature in the New Millennium. Advanced Science Letters, 23(9), 9271-9274.

[62] Keong, L., Ramakrishnan, S., \& Hishan, S. (2018). Corporate social responsibility practice of Malaysian public listed governmentlinked companies: A dimensional analysis. Management Science Letters, 8(5), 417-426. 